\title{
Biomineralization and
}

\section{Bioaccumulation of Europium by a Thermophilic Metal Resistant Bacterium}

\author{
Maleke Maleke ${ }^{1}$, Angel Valverde ${ }^{1}$, Jan-G Vermeulen ${ }^{1}$, Errol Cason', Alba Gomez-Arias ${ }^{1,2}$, \\ Karabelo Moloantoa ${ }^{1}$, Liza Coetsee-Hugo ${ }^{3}$, Hendrik Swart ${ }^{3}$, Esta van Heerden ${ }^{1,4}$ and \\ Julio Castillo ${ }^{1 *}$ \\ ${ }^{1}$ Department of Microbial, Biochemical and Food Biotechnology, University of the Free State, Bloemfontein, South Africa, \\ ${ }^{2}$ Institution of Groundwater Studies, University of the Free State, Bloemfontein, South Africa, ${ }^{3}$ Department of Physics, \\ University of the Free State, Bloemfontein, South Africa, ${ }^{4}$ IWATER Solutions, Bloemfontein, South Africa
}

\section{OPEN ACCESS}

Edited by:

lan M. Head,

Newcastle University, United Kingdom

Reviewed by:

Eric D. van Hullebusch UMR7154 Institut de Physique du Globe de Paris (IPGP), France Amy Michele Grunden, North Carolina State University, United States

${ }^{*}$ Correspondence: Julio Castillo castillohernandezj@ufs.ac.za

Specialty section: This article was submitted to Microbiological Chemistry and Geomicrobiology, a section of the journal Frontiers in Microbiology

Received: 26 July 2018 Accepted: 15 January 2019 Published: 30 January 2019

Citation:

Maleke $M$, Valverde $A$, Vermeulen J-G, Cason E,

Gomez-Arias A, Moloantoa K,

Coetsee-Hugo L, Swart H, van Heerden E and Castillo J (2019) Biomineralization and Bioaccumulation of Europium by a Thermophilic Metal Resistant Bacterium. Front. Microbiol. 10:81. doi: 10.3389/fmicb.2019.00081
Rare earth metals are widely used in the production of many modern technologies. However, there is concern that supply cannot meet the growing demand in the near future. The extraction from low-grade sources such as geothermal fluids could contribute to address the increasing demand for these compounds. Here we investigated the interaction and eventual bioaccumulation of europium (Eu) by a thermophilic bacterium, Thermus scotoductus SA-01. We demonstrated that this bacterial strain can survive in high levels (up to $1 \mathrm{mM}$ ) of Eu, which is hundred times higher than typical concentrations found in the environment. Furthermore, Eu seems to stimulate the growth of $T$. scotoductus SA-01 at low $(0.01-0.1 \mathrm{mM})$ concentrations. We also found, using TEM-EDX analysis, that the bacterium can accumulate Eu both intracellularly and extracellularly. FT-IR results confirmed that carbonyl and carboxyl groups were involved in the biosorption of Eu. Infrared and HRXPS analysis demonstrated that Eu can be biomineralized by T. scotoductus SA-01 as $\mathrm{Eu}_{2}\left(\mathrm{CO}_{3}\right)_{3}$. This suggests that $T$. scotoductus SA-01 can potentially be used for the biorecovery of rare earth metals from geothermal fluids.

Keywords: biomineralization, intracellular Eu bioaccumulation, rare earth metals, thermophile, Thermus scotoductus SA-01

\section{INTRODUCTION}

Rare earth metals are essential for the production of modern devices like solar cells, mobile phones and computers, as well as for biomedical applications (Yu et al., 2009; Bouzigues et al., 2011; Das and Das, 2013; Zhuang et al., 2015). For example, europium (Eu) luminescent complexes are excellent probes for several biological and biomedical applications such as organic light-emitting diode, sensing and targeting specific DNA structures, bioimaging, melamine detection in milk products, and cellular imaging (Dutta et al., 2016; Silva et al., 2017). Thus, there is an ever increasing demand for rare earth metals due to the sheer scale and the rapid evolution of the biotechnological market. Accordingly, novel sources for viable rare earth metal supply have been explored, among 
them metal-rich hydrothermal fluids (Wood and Shannon, 2003; Lo et al., 2014; Charrier and Ajo-Franklin, 2017). Indeed, elevated concentrations $(20-1133 \mathrm{nmol} / \mathrm{kg}$ ) of rare earth metals have been detected in geothermal waters of the Yellowstone National Park (Lewis et al., 1998).

Recovery technologies for these types of metals include chemical precipitation, chemical coagulation and ion exchange, among others (Mahmoud et al., 2008; Xie et al., 2014; Gunatilake, 2015; Khawassek et al., 2015). For example, chemical precipitation is widely used for metal recovery from inorganic liquid solutions (Gunatilake, 2015). Metals can be easily precipitate by the addition of precipitant agents or by $\mathrm{pH}$ adjustment (Mahmoud et al., 2008). However, this process requires a large amount of chemicals, which produce large amounts of sludge (Khawassek et al., 2015). In contrast, biological approaches (e.g., bioaccumulation and biomineralization) are more cost effective and environmentally friendly (Volesky, 2001, 2007; Diniz and Volesky, 2005). Furthermore, they seem to perform very well to recover metal ions from very dilute solutions with moderate to low grade of rare earth metals, which is a common feature of geothermal fluids (Das et al., 2010; Lo et al., 2014). Nevertheless, most of these studies have been performed with mesophilic microorganisms.

Thermophilic and hyper thermophilic bacteria and archaea, such as chemoautotrophic sulfur reducer and oxidizers, also interact with metals (Hetzer et al., 2006; Babák et al., 2012; Jiang et al., 2012; Naik and Furtado, 2017). For instance, a comparative investigation on the uptake of heavy metals $\left(\mathrm{Cd}^{2+}\right.$, $\mathrm{Cu}^{2+}, \mathrm{Co}^{2+}$, and $\mathrm{Mn}^{2+}$ ) in Geobacillus thermantarcticus and Anoxybacillus amylolyticus showed high affinity of metals for the cell envelope (Özdemir et al., 2013). On a dry weight basis, $G$. thermantarcticus was able to bind higher amounts of $\mathrm{Cd}$ and $\mathrm{Mn}$ more than A. amylolyticus. In general, the microbial binding capacity of metals is approximately on the order of $10^{-5}$ to $10^{-3}$ mol metal $\mathrm{g}^{-1}$ (dry weight) microbe, which compares to the binding capacities of commercial ion exchangers (Vijayaraghavan and Yun, 2008). Yet, to our knowledge, only one study using Geobacillus stearothermophilus as a biosorbent has recently investigated how thermophilic bacteria interact with rare earth metals (Charrier and Ajo-Franklin, 2017). Here we report the bioaccumulation and biomineralization of Eu by Thermus scotoductus SA-01, which was isolated from fissure water sampled at a depth of $3.2 \mathrm{~km}$ (Mponeng Gold Mine, South Africa) (Kieft et al., 1999). The organism is of interest because of its ability to interact with a variety of metals (Kieft et al., 1999; Opperman and van Heerden, 2007; Cason et al., 2012; Erasmus et al., 2014) under thermophilic conditions.

\section{MATERIALS AND METHODS}

\section{Cultivation Conditions}

Unless stated otherwise, T. scotoductus SA-01 was cultivated under anaerobic conditions in complex organic media TYG (5 g/L Tryptone; $3 \mathrm{~g} / \mathrm{L}$ Yeast Extract, and $1 \mathrm{~g} / \mathrm{L}$ Glucose, $\mathrm{pH}$ $7.0)$ at $65^{\circ} \mathrm{C}$ on a rotary shaker $(160 \mathrm{rpm})$. Cell concentrations were determined by extrapolating $\mathrm{OD}_{600 \mathrm{~nm}}$ to dry biomass values using a calibration curve.

\section{Tolerance to Europium}

Thermus scotoductus SA-01 cells were grown to mid-exponential growth phase $\left(\mathrm{OD}_{600 \mathrm{~nm}}=0.8\right)$, inoculated (1:10 dilution, approximately $0.06 \mathrm{~g} / \mathrm{L}$ dry weight) into fresh TYG medium containing Eu $(0,0.01,0.05,0.1,0.5,1$, and $2 \mathrm{mM})$ and grown for $24 \mathrm{~h}$. Differences in bacterial growth between cultures were monitored spectrophotometrically $\left(\mathrm{OD}_{600 \mathrm{~nm}}\right)$ taking samples at $2 \mathrm{~h}$ intervals. The experiment was performed in triplicate.

\section{Removal of Europium}

A standardized cell suspension (0.06 g/L dry weight) was used as an inoculum to initiate growth with $0.5 \mathrm{mM}$ of $\mathrm{Eu}^{3+}$. After recording the optical density, $1 \mathrm{~mL}$ samples were centrifuged $(6,000 \times g ; 5 \mathrm{~min})$ and the removal of $\mathrm{Eu}$ was evaluated by monitoring the decrease in total $\mathrm{Eu}^{3+}$ concentration in the media over time using the arsenazo-III method (Uhrovčík et al., 2013). Briefly, samples $(0.5 \mathrm{~mL})$ were added to $1 \mathrm{~mL}$ of a $0.1 \mathrm{M}$ potassium hydrogen phthalate buffer solution, followed by $0.4 \mathrm{~mL}$ of the $0.05 \%$ chromogenic reagent dissolved in water. The reaction mixture was filled with deionized water to a final volume of $5 \mathrm{~mL}$ and mixed thoroughly. $\mathrm{Eu}^{3+}$ was quantified using a calibration curve relating $\mathrm{Eu}^{3+}$ concentration to absorbance at $655 \mathrm{~nm}$ (0.998 correlation coefficient) measured using a GENESYS 5 (Thermo Fisher Scientific, United States) spectrophotometer. Negative controls were used to assess abiotic $\mathrm{Eu}^{3+}$ removal.

\section{Cellular Distribution of Europium}

The accumulation of $\mathrm{Eu}^{3+}$ by different subcellular fractions of T. scotoductus SA-01 was evaluated using the methodology described by Gaspard et al. (1998). Briefly, cells exposed to $\mathrm{Eu}^{3+}$ were harvested by centrifugation $(6,000 \times g ; 15 \mathrm{~min}$; $4^{\circ} \mathrm{C}$ ) and approximately $1 \mathrm{~g}$ of cells washed with $20 \mathrm{mM}$ MOPS-NaOH buffer ( $\mathrm{pH}$ 7.0). Spheroplasts were prepared by resuspending $\sim 1$ g wet weight xperiment when concecells in $20 \mathrm{~mL}$ of buffer containing 25\% (w/v) sucrose. Lysozyme was added to a final concentration of $0.1 \%(\mathrm{w} / \mathrm{v})$ and slowly mixed on a tube roller mixer for $20 \mathrm{~min}$ in order to degrade the cellular wall. EDTA ( $\mathrm{pH}$ 8.0) was added to a final concentration of $5 \mathrm{mM}$ to the lysis buffer and slowly shaken for additional 20 min. Magnesium chloride $\left(\mathrm{MgCl}_{2}\right)$ was added to a final concentration of $13 \mathrm{mM}$ and the suspension was further shaken for $20 \mathrm{~min}$. Separation of spheroplast from the periplasmic fraction was achieved by centrifugation $(20,000 \times g ; 30 \mathrm{~min}$; $\left.4^{\circ} \mathrm{C}\right)$. Spheroplasts were resuspended in $10 \mathrm{~mL}$ of $20 \mathrm{mM}$ MOPS$\mathrm{NaOH}$ buffer (pH 7.0).

To obtain the membrane and cytoplasmic fractions, cells were disrupted by ultrasonic treatment $(6$ repeats, $100 \mathrm{~W}, 30 \mathrm{~s}$ on ice) with a Branson Sonic Power Sonifier Cell Disruptor B-30 (Danbury, United States). Cell debris was removed by centrifugation $\left(4,000 \times g ; 10 \mathrm{~min} ; 4^{\circ} \mathrm{C}\right)$. The crude extract (supernatant) was subsequently centrifuged $(100,000 \times g ; 90 \mathrm{~min}$; $4^{\circ} \mathrm{C}$ ), yielding a cytoplasmic fraction containing soluble proteins (supernatant) and a membrane fraction (pellet). The latter 
fraction was resuspended in MOPS-NaOH buffer $(20 \mathrm{mM}$, $\mathrm{pH}$ 7.0) and the concentrations of $\mathrm{Eu}$ in all fractions were immediately determined using the arsenazo-III method.

\section{Scanning and Transmission Electron Microscopy}

Electron microscopy was utilized to investigate the sorption and/or accumulation of Eu. T. scotoductus SA-01 cells exposed to $0.5 \mathrm{mM} \mathrm{Eu}$ were harvested by centrifugation $(6,000 \times g$; $\left.15 \mathrm{~min} ; 4^{\circ} \mathrm{C}\right)$. For SEM, the cells were fixed in $2.5 \%(\mathrm{v} / \mathrm{v})$ glutaraldehyde, and dehydrated. Thereafter, the cells were critical point dried, mounted on metal stubs, coated with gold and analyzed using a JSM-7800F thermal field emission scanning microscope (FE-SEM) coupled with Oxford Aztec 350 X-Max80 energy-dispersive X-ray (EDX) analysis (Oxford Instruments, United Kingdom). For TEM, the cell pellets were subjected to fixation, dehydration, and polymerization. Thin sections $(0.2 \mu \mathrm{m})$ were cut and trimmed with an ultramicrotome UM7 (Leica Microsystems, Germany) and collected on copper grids. Transmission electron micrographs were taken with a Philips CM100 (FEI, United States) coupled with an Oxford X-ray analyzer coupled with energy dispersive X-ray (EDX) spectrum (JSM-7800F) (Oxford Instruments, United Kingdom).

\section{Fourier Transform Infrared (FT-IR) Spectroscopy}

Fourier transform infrared spectroscopy was used to elucidate functional groups interacting with Eu. After centrifugation as above, the bacterial cells were dried overnight by lyophilization under vacuum and analyzed using a Bruker Tensor 27 model (Bruker, Germany). The spectral analysis was done in the mid IR region (500-4000 $\mathrm{cm}^{-1}$ ) with 16 scan speed. Peaks were identified based on previously reported data.

\section{High-Resolution X-Ray Photoelectron Spectroscopy (HR-XPS)}

High-resolution X-ray photoelectron spectroscopy was used to determine both $\mathrm{Eu}$ oxidation state and neoformed mineral phases. HR-XPS was obtained with a PHI 5000 Versaprobe system (Physical Electronics, United States). Briefly, after incubation following standard conditions, bacterial cells were harvested by centrifugation $(6000 \times g$; $15 \mathrm{~min} ; 4^{\circ} \mathrm{C}$ ), the pellets were dried under vacuum by lyophilization, embedded on a carbon tape and then analyzed in a vacuum chamber. A low energy Ar iongun and low energy neutralizer electron-gun were used to minimize charging on the surface. A $100 \mu \mathrm{m}$ diameter monochromatic Al K $\alpha$ x-ray beam (hv1/4 $1486.6 \mathrm{eV})$ generated by a $25 \mathrm{~W}, 15 \mathrm{kV}$ electron beam was used to analyze the different binding energy peaks. The pass energy was set to $11 \mathrm{eV}$ giving an analyzer resolution of $0.5 \mathrm{eV}$. Multipack version 8.2 software (Ulvac-PHI, Inc., Japan) was utilized to analyze the spectra to identify the chemical compounds present and their electronic states using Gaussian-Lorentz fits.

\section{RESULTS}

\section{Tolerance to Europium}

The growth of $T$. scotoductus SA-01 in TYG medium was identical when exposed to concentrations between 0.01 and $1 \mathrm{mM}$ of $\mathrm{Eu}^{3+}$ (Figure $\mathbf{1}$ and Table 1), although slower growth was observed at the beginning of the experiment when concentration

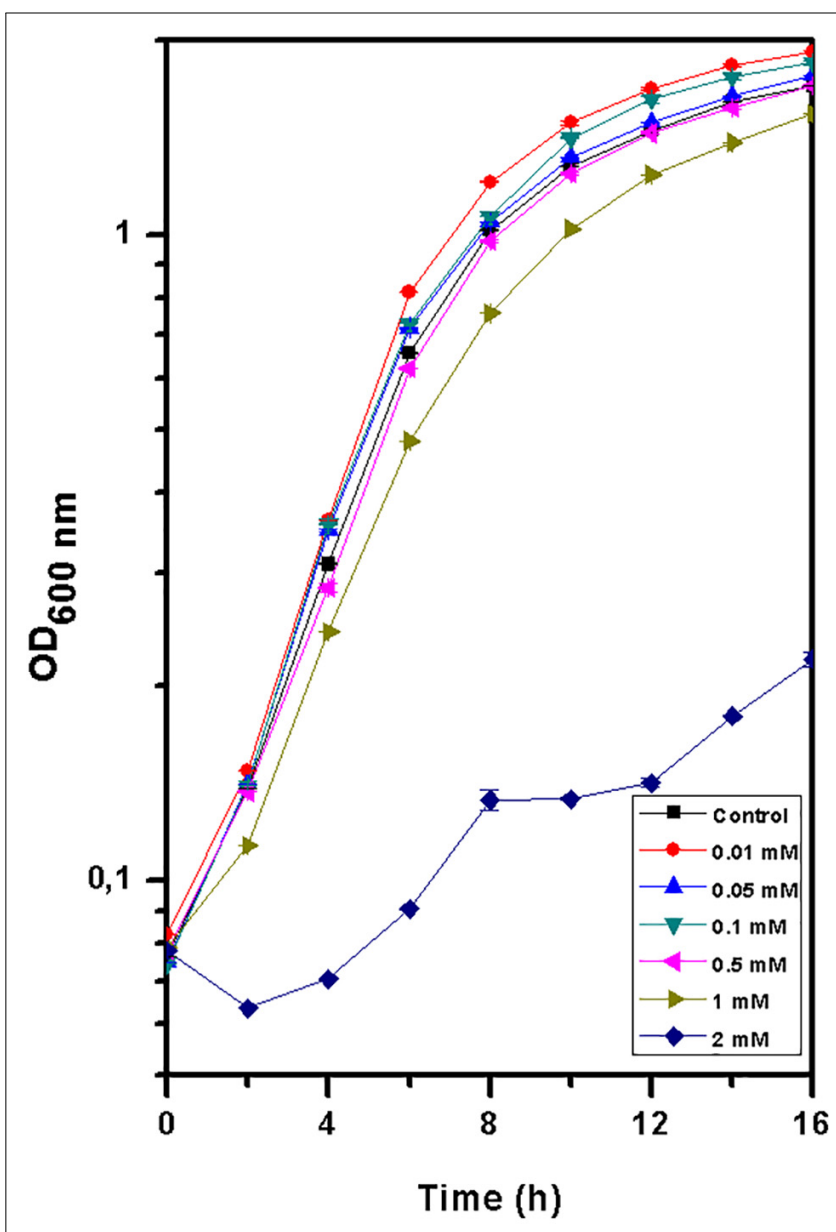

FIGURE 1 | Growth curve of Thermus scotoductus SA-01 in TYG media over a $16 \mathrm{~h}$ period. Symbols indicate the mean value of $\mathrm{OD}_{600 \mathrm{~nm}}$ samples. Standard deviations are included but are negligible.

TABLE 1 | Specific growth rate and doubling time values for Thermus scotoductus SA-01 grown in different $\mathrm{Eu}(0,0.01,0.05,0.1,0.5,1$, and $2 \mathrm{mM})$ concentrations.

\begin{tabular}{lcc}
\hline Concentration & $\boldsymbol{\mu} \mathbf{M a x}\left(\mathbf{h}^{-\mathbf{1}}\right)$ & $\mathbf{t d}(\mathbf{h})$ \\
\hline Control $(0 \mathrm{mM})$ & $0.34 \pm 1.9 E-04$ & $2.14 \pm 5.4 E-03$ \\
$0.01 \mathrm{mM}$ & $0.39 \pm 3.5 E-04$ & $1.81 \pm 3.2 E-03$ \\
$0.05 \mathrm{mM}$ & $0.38 \pm 2.4 E-04$ & $1.82 \pm 1.5 E-03$ \\
$0.1 \mathrm{mM}$ & $0.37 \pm 1.1 E-04$ & $1.84 \pm 1.2 E-03$ \\
$0.5 \mathrm{mM}$ & $0.35 \pm 2.3 E-04$ & $2.04 \pm 6.4 E-03$ \\
$1 \mathrm{mM}$ & $0.31 \pm 9.2 E-04$ & $2.47 \pm 7.2 E-03$ \\
$2 \mathrm{mM}$ & BD* & -
\end{tabular}

*BD, below detection limit. 
of Eu were $>0.5 \mathrm{mM}$. In contrast, no growth was observed at $2 \mathrm{mM}$ of Eu, suggesting that at this concentration $\mathrm{Eu}$ is toxic for this bacterium.

\section{Removal of Europium}

Europium was totally removed by $T$. scotoductus SA-01 within $10 \mathrm{~h}$ of incubation during the exponential growth phase (Figure 2). We note that Eu precipitation also took place in the negative controls, but in lower amount than in the presence of T. scotoductus SA-01, likely due to the change in physicochemical parameters other than $\mathrm{pH}$, as $\mathrm{pH}$ did not vary significantly and kept neutral until the end of the experiments (from 7 to 6.5 on average).

\section{Bioaccumulation of Europium}

Scanning electron micrographs showed that most of the cells exposed to Eu were similar in morphology to those unexposed (Figure 3). Several collapsed cells were found in the preparations but with a similar rod-shaped form as those of the control cells

(Figure 3b). Metal precipitates were also observed and electron dispersion X-ray (EDX) spectroscopy analyses revealed that the precipitates were mainly composed of $\mathrm{Eu}, \mathrm{P}, \mathrm{C}$, and $\mathrm{O}$ (inset Figure 3b).

Transmission electron microscopy coupled to EDX spectra analysis corroborated that most Eu deposits accumulated on the cell surface (Figures $\mathbf{4 a}, \mathbf{b}$ ), although Eu precipitates were also intracellularly accumulated (Figure $4 \mathbf{b}$ ). The presence of the intense copper $(\mathrm{Cu})$ peak is attributed to the copper grid used for sample collection.

Similar results were obtained after the separation of the different subcellular fractions. Approximately 78\% of the $\mathrm{Eu}^{3+}$ retained $(0.36 \mathrm{mM}$ out of $0.5 \mathrm{mM})$ by the bacterium was found on the cell surface, $17 \%$ on the cytoplasmic membrane and $5 \%$ in the cytoplasm. We did not detect any $\mathrm{Eu}^{3+}$ in the periplasmic fraction.

\section{Surface Characterization}

The interaction between the cell wall and Eu was further assessed by Fourier transform infrared (FTIR) analysis. The FTIR spectra were in the range of $500-4000 \mathrm{~cm}^{-1}$ (Figure 5 and Table 2).

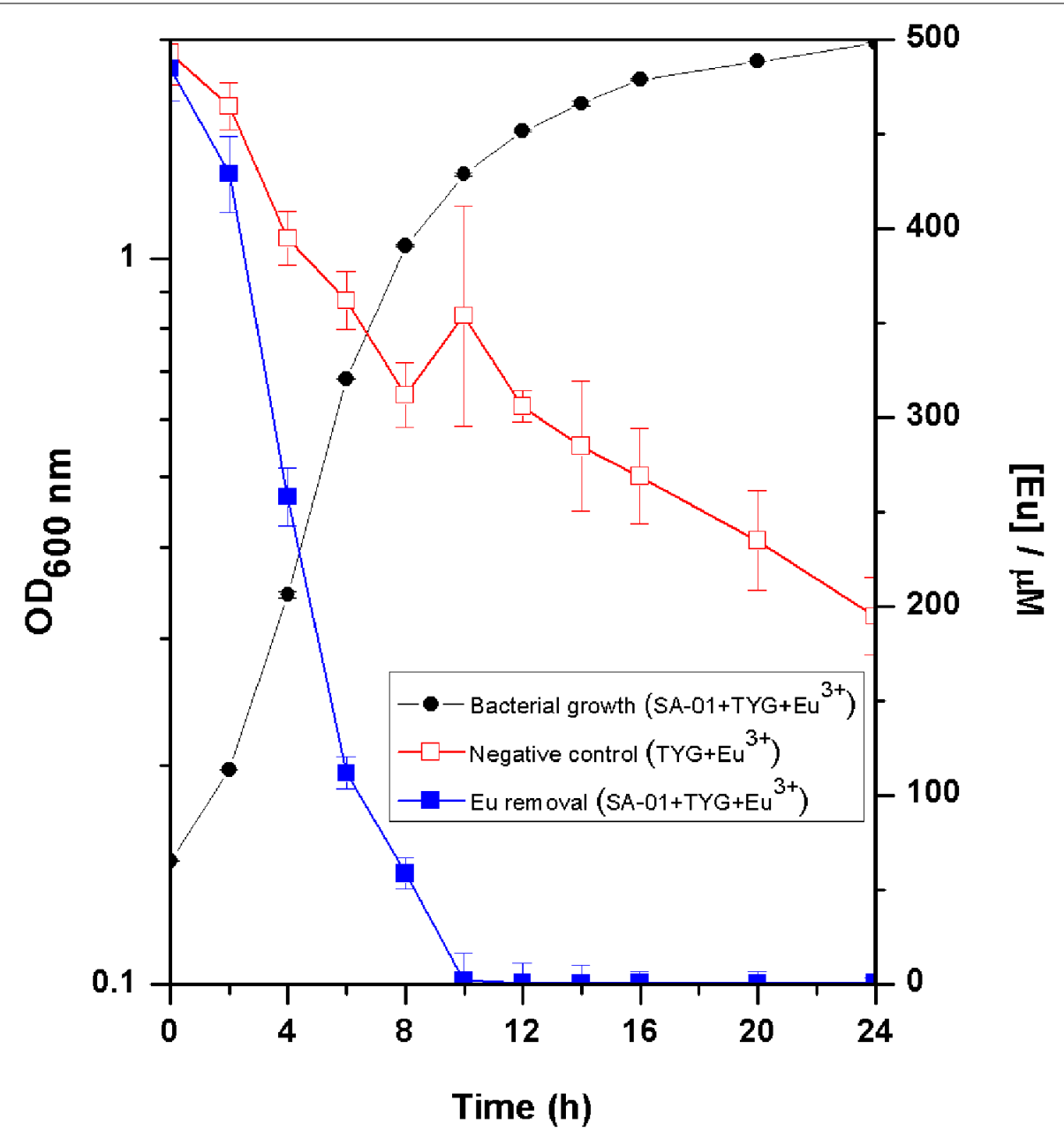

FIGURE 2 | Growth curve of T. scotoductus SA-01 supplemented with 0.5 mM Eu ${ }^{3+}$ in TYG media. Error bars indicate standard deviation, while symbols indicate mean values. 


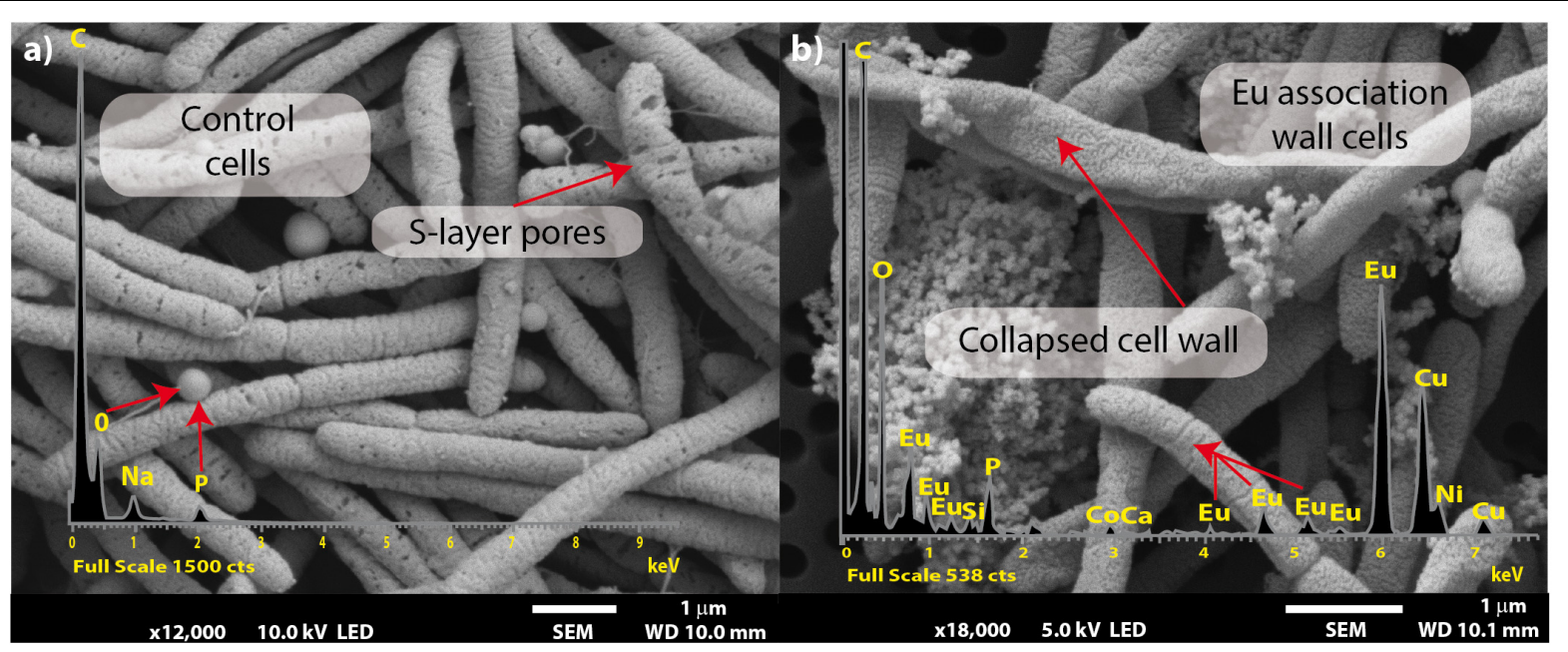

FIGURE 3 | Scanning electron microscopy micrographs of T. scotoductus SA-01. Bars indicate the scale as micrometers and red arrows indicate EDX spectra. Control (a) and Eu amended cells (b).

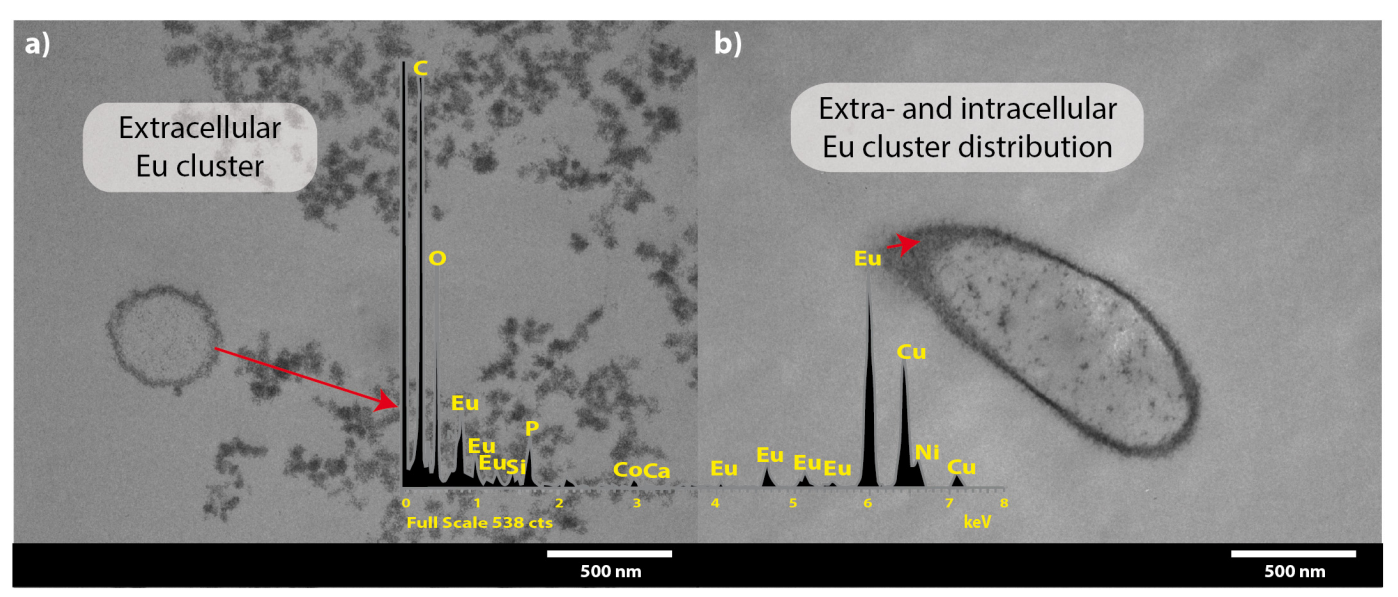

FIGURE 4 | Transmission electron microscopy micrographs of T. scotoductus SA-01 amended with 0.5 mM Eu. White bars indicate the scale in nanometers and red arrows show the location and distribution of Eu (shown as electron-dense granules). Europium biosorption (a) and intracellular bioaccumulation (b). Insets show energy-dispersive X-ray spectra.

Prominent peaks in the loaded biomass were observed at 621.7, $1002.4,1066.4$, and $2356.6 \mathrm{~cm}^{-1}$. While, the intensity of some peaks (at 1228.1, 1538.5, 1641.9, 2926.7, and $3292.7 \mathrm{~cm}^{-1}$ ) in the loaded biomass was substantially lower than the unloaded biomass. The peak stretching and intensity demonstrate a change in the amount of the functional group associated with the molecular bond. Whereas a shift in peak position demonstrates the hybridization state in the molecular bond has changed. The spectra showed a distinctive peak at $621.7 \mathrm{~cm}^{-1}$ attributed to $\mathrm{PO}_{4}{ }^{3-}$ in the loaded biomass, which is absent in the control samples. Peaks attributed to organic phosphate and $\mathrm{C}-\mathrm{PO}_{3}{ }^{2-}$ (1002.4 and $\left.1066.4 \mathrm{~cm}^{-1}\right), \mathrm{CO}_{2}\left(2356.6 \mathrm{~cm}^{-1}\right)$ and alkyl chain bands (around 2850-2955 $\mathrm{cm}^{-1}$ ) were also observed. Low intensity peaks were also noted, for instance, peaks between 1056 and $1233 \mathrm{~cm}^{-1}$, which are attributed to $\mathrm{P}-\mathrm{O}$ of $\mathrm{C}-\mathrm{PO}_{3}{ }^{2-}$ moiety region and $\mathrm{P}=\mathrm{O}$, as well as, lower intensity peaks around 1400 and $1600 \mathrm{~cm}^{-1}$, which contribute to the amide I and II regions of proteins, were reduced in cells binding Eu. The amide II region consists of $\mathrm{N}-\mathrm{H}$ bending and $\mathrm{C}-\mathrm{N}$ stretching vibrations close to the region of $1520-1550 \mathrm{~cm}^{-1}$. While, amide I is usually the region at $1633 \mathrm{~cm}^{-1}$ but in the experiments shifted to $1641 \mathrm{~cm}^{-1}$, which was caused by $\mathrm{C}=\mathrm{O}$ stretching. Overall, the spectra indicated that the interaction occurs mainly through the phosphate, carboxyl and carbonyl of amide groups.

\section{Biomineralization of Europium}

The fitted curve of the HR-XPS spectra indicated two major peaks at 1135.1 and $1131.6 \mathrm{eV}$ (Figure 6). The HR-XPS analysis revealed that the Eu was in the 3+ oxidation state. According to Mercier et al. (2006), the $1135.1 \mathrm{eV}$ peak was identified as Eu carbonate $\left[\mathrm{Eu}_{2}\left(\mathrm{CO}_{3}\right)_{3}\right]$. 


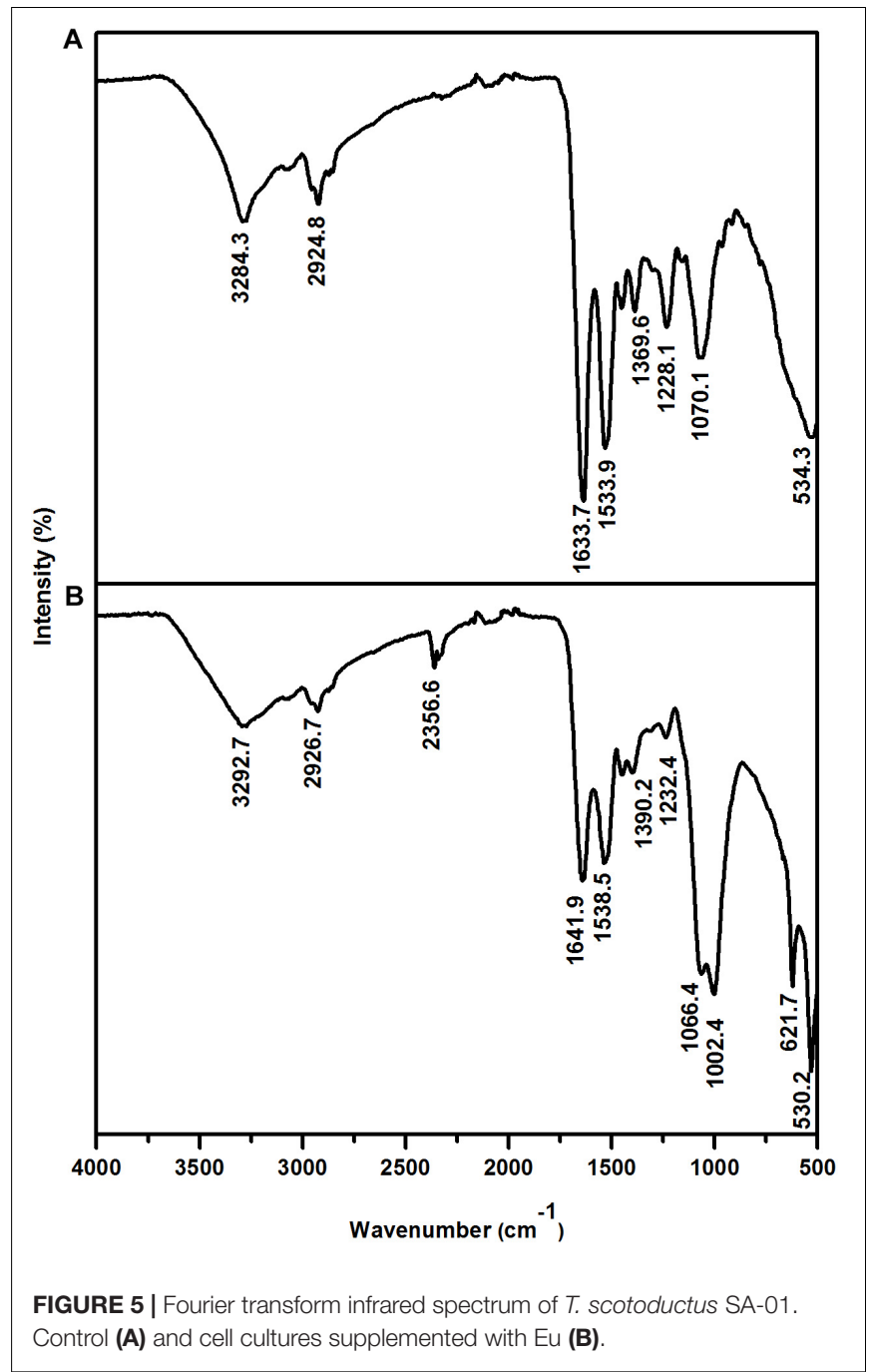

\section{DISCUSSION}

Rare earth metals, including Eu, have recently been found to play an important role in the biology of different bacteria ( $\mathrm{Pol}$ et al., 2014; Jahn et al., 2018). Here we found that Eu promotes the growth of T. scotoductus SA-01 at low concentration (up to $0.1 \mathrm{mM}$ ), while it is detrimental at high concentrations $(>0.5 \mathrm{mM})$. This is in accordance with the results reported by Azabou et al. (2007) in Desulfomicrobium species, a mesophilic bacterium. Similarly, Pol et al. (2014) showed that the growth of Methylacidiphilum fumariolicum SoIV (thermophilic) was affected by rare earth metals. Comparatively, the tolerance of T. scotoductus SA-01 is higher than that of other bacterial strains reported to tolerate rare earth metals. For example, Bacillus sp. $\mathrm{W}-28$ and S. acidiscabies W-12 (both mesophilic) can tolerate 0.05 and $0.2 \mathrm{mM}$ of La, respectively (Haferburg et al., 2007). Conversely, T. scotoductus SA-01 tolerance is lower than that reported for K. vulgare (mesophilic) which is able to tolerate $5 \mathrm{mM}$ of La (Lyu et al., 2014). In general, the toxicity of metals in bacteria results from the displacement or substitution of
TABLE 2 | Assignment of FTIR derived peaks to functional groups of T. scotoductus SA-01.

\begin{tabular}{|c|c|c|c|}
\hline \multicolumn{2}{|c|}{ Wavenumber $\left(\mathrm{cm}^{-1}\right)$} & \multirow[b]{2}{*}{ Assignment } & \multirow[b]{2}{*}{ Reference } \\
\hline Control & Europium & & \\
\hline 1010.1 & 1002.4 & Organic phosphate & Hosomomi et al., 2013 \\
\hline- & 1066.4 & $\mathrm{P}-\mathrm{O}$ of $\mathrm{C}-\mathrm{PO}_{3}{ }^{2-}$ & $\begin{array}{l}\text { Hosomomi et al., 2013; } \\
\text { Oves et al., } 2013\end{array}$ \\
\hline 1228.1 & 1232.4 & $\mathrm{P}=\mathrm{O}$ phosphodiester & $\begin{array}{l}\text { Kamnev et al., 2002; } \\
\text { Hosomomi et al., 2013; } \\
\text { Oves et al., } 2013\end{array}$ \\
\hline 1369.6 & 1390.2 & $\begin{array}{l}\mathrm{COO}^{-}(\text {carboxyl) and } \\
\mathrm{C}-\mathrm{O}-\mathrm{C}\end{array}$ & $\begin{array}{l}\text { Emmanuel et al., 2011; } \\
\text { Hosomomi et al., } 2013\end{array}$ \\
\hline 1533.9 & 1536.5 & $\begin{array}{l}\text { Amide II; N-H and C-N } \\
\text { group }\end{array}$ & $\begin{array}{l}\text { Adochitei and } \\
\text { Drochioiu, 2011; } \\
\text { Hosomomi et al., 2013; } \\
\text { Oves et al., } 2013\end{array}$ \\
\hline 1633.7 & 1641.9 & $\begin{array}{l}\text { Amide I; C = O group } \\
\text { (carbonyl) }\end{array}$ & $\begin{array}{l}\text { Adochitei and } \\
\text { Drochioiu, 2011; } \\
\text { Hosomomi et al., 2013; } \\
\text { Oves et al., } 2013\end{array}$ \\
\hline 2924.8 & 2926.7 & $\begin{array}{l}\mathrm{C}-\mathrm{H} \text { stretching and } \\
\text { alkyl group }\end{array}$ & $\begin{array}{l}\text { Hosomomi et al., 2013; } \\
\text { Oves et al., } 2013\end{array}$ \\
\hline 3284.3 & 3292.7 & $\begin{array}{l}\text { O-H of carboxyl } \\
\text { stretching/N-H } \\
\text { stretching }\end{array}$ & $\begin{array}{l}\text { Kamnev et al., 2002; } \\
\text { Emmanuel et al., } 2011\end{array}$ \\
\hline
\end{tabular}

essential elements from cellular sites and due to the blocking of functional groups of important biochemical molecules (Cason et al., 2012). For instance, rare earth metals can replace calcium ions in the binding sites of nucleases, affecting bacterial growth (Balasubramanian et al., 2014).

Rare earth metals substantially change bacterial cell walls particularly those of gram-negative bacteria (Peng et al., 2004; Chen et al., 2010, 2012). Likewise, we also found morphological changes in the bacterial cells treated with Eu. In general, the cell wall has high affinity for metals in solution (Mishra et al., 2010; MacHalová et al., 2015), which bind to cell surface receptors such as S-layer proteins and other organic molecules (Borrok et al., 2007; Hosomomi et al., 2013; MacHalová et al., 2015). The SEM and TEM micrographs and cellular fractionation showed that $\mathrm{Eu}$ accumulates (in decreasing order), on the cell surface of the bacterial envelopes, in the membrane and in the cytoplasm, but not in the periplasmic space. These results are in contrast to what was observed in E. coli, which was able to accumulate rare earth metals in the periplasmic space (Bayer and Bayer, 1991). We did not investigate the molecular mechanism that allow Eu to enter the cytoplasm, but previous studies using this bacterium and other metals (i.e., $\mathrm{U}$ and $\mathrm{Au}$ ) seem to indicate that $\mathrm{ABC}$ transporters (Cason et al., 2012; Erasmus et al., 2014) may play a role. On the other hand, the intracellular accumulation of Eu might be mediated by PolyP metabolism. Indeed, transmission electron microscopy and EDX analysis showed electron dense granules in the cytoplasm composed of Eu and phosphate. Furthermore, T. scotoductus SA-01 harbors polyphosphate kinases (ppk) and exopolyphosphatases (ppx) genes, which are responsible for the synthesis and degradation of PolyP, respectively. PolyP is often 

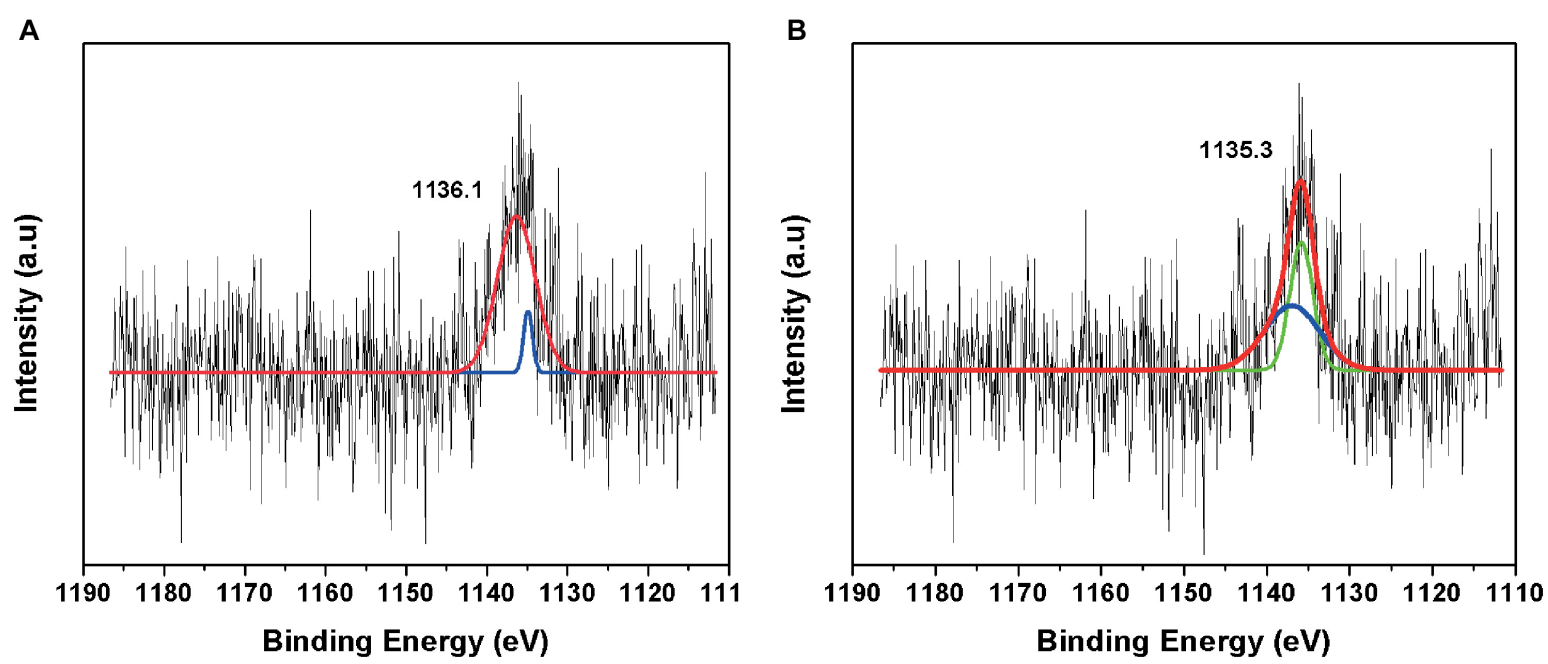

FIGURE 6 | High-resolution XPS spectrum of (A) negative control amended with Eu and (B) minerals formed in TYG media amended with Eu and T. scotoductus SA-01.

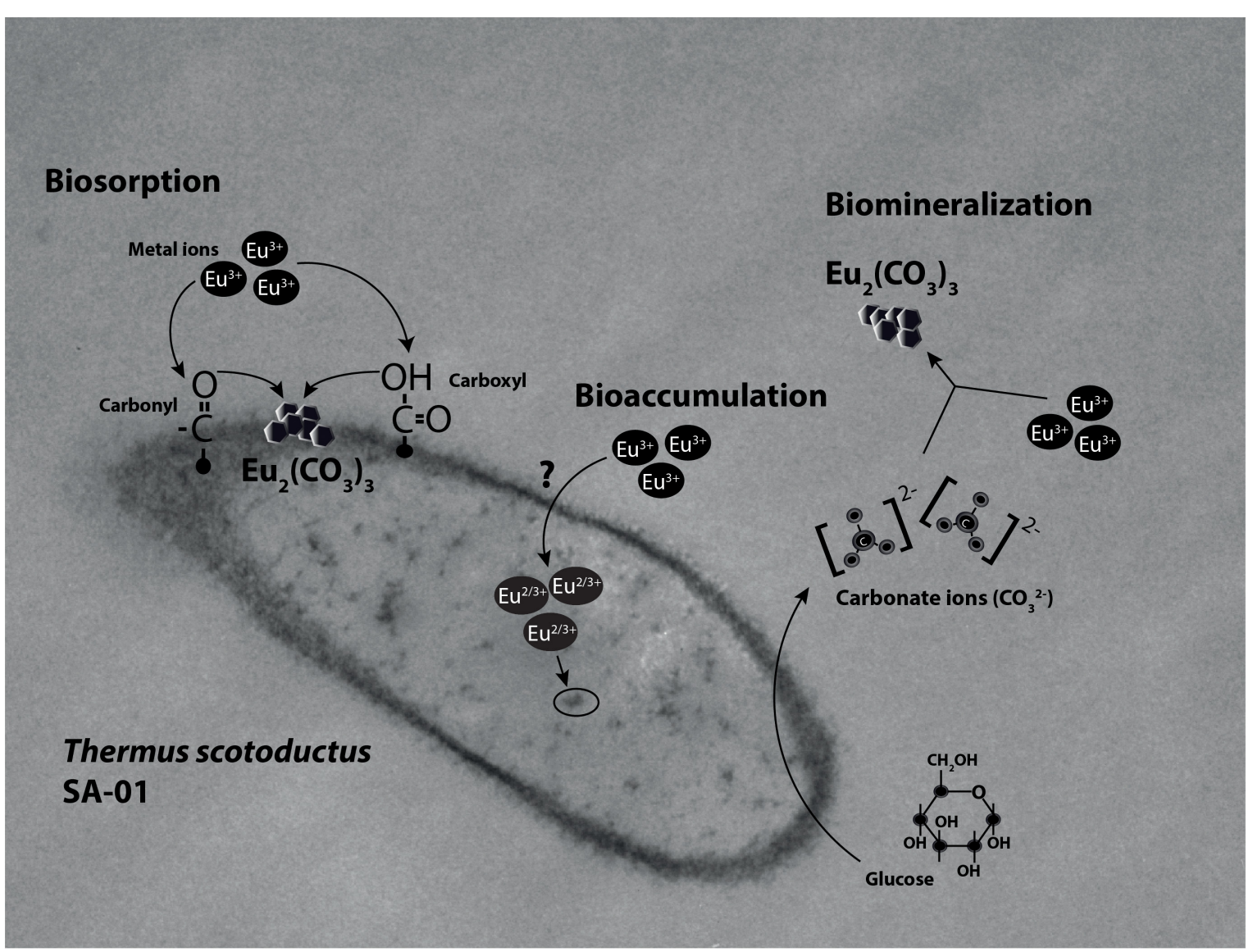

FIGURE 7 | Illustration of the interaction mechanisms of T. scotoductus SA-01 with Europium.

involved in metal accumulation and detoxification in bacteria (Rao and Kornberg, 1996; Kuroda et al., 1999; Nikel et al., 2013) as a defense mechanism against environmental stress.
Overall, the data seem to indicate that there is a rapid phase of metal binding to the cell surface (biosorption) that is followed by a slower phase of metal bioaccumulation into the cell. 
We further investigated which functional groups could be involved in the biosorption of Eu. The FT-IR results showed that peaks associated with functional groups such as phosphates $\left(\mathrm{PO}_{4}\right)$, carboxyl $(\mathrm{COOH})$ and carbonyl $(\mathrm{C}=\mathrm{O})$ of amide groups, commonly found as organic molecules released by microorganism, become more evident after the incubation with Eu (Benzerara et al., 2005). These functional groups as well as others (e.g., aldehyde, hydroxyl, ketone) are commonly involved in the biosorption of metals in mesophilic bacteria (Madrid and Camara, 1997; Saleem et al., 2008), but few reports are available on thermophiles (Özdemir et al., 2013). Elements such as $\mathrm{Ca}^{2+}$ can react with $\mathrm{COOH}$ and $\mathrm{C}=\mathrm{O}$ groups to form various chelate complex $\left[\mathrm{Ca}_{\mathrm{x}}{ }^{2+}(\mathrm{CO})_{\mathrm{y}}\right]^{\mathrm{n}}$ (Qian et al., 2010). Interestingly, Europium $\left(\mathrm{Eu}^{3+/ 2+}\right)$ has similar ionic charge and radius to $\mathrm{Ca}^{2+}$, which facilitate the replacement of $\mathrm{Ca}$ by $\mathrm{Eu}$ in mineral structures (Homer and Mortimer, 1978; Hellebrandt et al., 2016). This suggests the biomineralization of $\mathrm{Eu}$ as neoformed mineral complex $\left[\mathrm{Eu}_{\mathrm{x}}{ }^{+}(\mathrm{CO})_{\mathrm{y}}\right]^{\mathrm{n}}$ on the cell wall. Indeed, HRXPS analysis demonstrate that the phase minerals bound to the cell surface of $T$. scotoductus SA-01 were $\mathrm{Eu}_{2}\left(\mathrm{CO}_{3}\right)_{3}$. However, a significant drawback to this technique is that it only provides information with regards to surface binding of Eu (Kumar et al., 2015). Usually, reduction of metals leads to intracellular bioaccumulation as it was observed in bacterium Paracoccus denitrificans interaction with $\mathrm{Cu}$ (Su et al., 2015). Therefore, it is possible that a fraction of Eu accumulated intracellularly might exist in the divalent state.

Microorganisms can also induce the precipitation of minerals by modifying the conditions of their surrounding microenvironments (De Muynck et al., 2013; Sánchez-Román et al., 2015; Zhu and Dittrich, 2016). Under neutral to alkaline $\mathrm{pH}$, the carbon dioxide produced by respiration reacts easily with $\mathrm{OH}^{-}$radicals leading to the formation of carbonate minerals. For example, Sánchez-Román et al. (2015) reported that the increase in $\mathrm{CO}_{3}{ }^{2-}$ induced $\mathrm{Fe}$-carbonate mineralization in Tessarococcus lapidicaptus. Several studies have also reported on the external precipitation of Ca-carbonate by Cyanobacteria (Obst et al., 2006; Kamennaya et al., 2012; Benzerara et al., 2014). Altogether, it seems that the presence of $T$. scotoductus SA-01 can induce the biomineralization of $\mathrm{Eu}$ in two different ways: (1) by modifying

\section{REFERENCES}

Adochitei, A., and Drochioiu, G. (2011). Rapid characterization of peptide secondary structure by FTIR spectroscopy. Rev. Roum. Chim. 56, 783-791.

Azabou, S., Mechichi, T., Patel, B. K. C., and Sayadi, S. (2007). Isolation and characterization of a mesophilic heavy-metals-tolerant sulfatereducing bacterium Desulfomicrobium sp. from an enrichment culture using phosphogypsum as a sulfate source. J. Hazard. Mater. 140, 264-270. doi: 10.1016/j.jhazmat.2006.07.073

Babák, L., Šupinová, P., Zichová, M., Burdychová, R., and Vítová, E. (2012). Biosorption of $\mathrm{Cu}, \mathrm{Zn}$ and $\mathrm{Pb}$ by thermophilic bacteria - Effect of biomass concentration on biosorption capacity. Acta Univ. Agric. Silvic. Mendelianae Brun. 60, 9-18. doi: 10.11118/actaun201260050009

Balasubramanian, B., Mukherjee, P., Skomski, R., Manchanda, P., Das, B., and Sellmyer, D. J. (2014). Magnetic nanostructuring and overcoming Brown's paradox to realize extraordinary high-temperature energy products. Sci. Rep. 4, 6265-6276. doi: 10.1038/srep06265 the conditions of its surrounding microenvironments and/or (2) acting as nucleation sites (Figure 7).

\section{CONCLUSION}

Our findings provide information on how $T$. scotoductus SA-01 interacts with Eu under thermophilic conditions. This is important because temperature is a limiting factor when exploring metal recovery from geothermal fluids by biological processes and for the use of bacteria in other industrial applications. We conclude that $T$. scotoductus SA-01 can be employed for the biorecovery of Eu and other rare earth metals in rare earth metal-containing carbonates.

\section{AUTHOR CONTRIBUTIONS}

MM, JC, JV, EC, and EvH designed the research. MM and KM performed the experiments. AG-A helped with ICP-MS analysis and data interpretation. LC-H and HS helped with HR-XPS analysis and data interpretation. MM wrote the first draft of the manuscript. MM, AV, JC, JV, EC, KM, and EvH wrote the final manuscript. All authors read and approved the final manuscript.

\section{FUNDING}

This research was conducted with financial support from the Technology and Innovation Agency and National Research funding of South Africa (88833 and 106460).

\section{ACKNOWLEDGMENTS}

The authors thank the staff of the Centre for Microscopy (University of the Free State, South Africa) for assisting with SEM and TEM-EDX analysis and the Department of Chemistry (University of the Free State, South Africa) for assisting with FT-IR analysis.
Bayer, M. E., and Bayer, M. H. (1991). Lanthanide accumulation in the periplasmic space of Escherichia coli B. J. Bacteriol. 173, 141-149. doi: 10.1128/jb.173.1.141149.1991

Benzerara, K., Menguy, N., Guyot, F., Vanni, C., and Gillet, P. (2005). TEM study of a silicate-carbonate-microbe interface prepared by focused ion beam milling. Geochim. Cosmochim. Acta 69, 1413-1422. doi: 10.1016/j.gca.2004. 09.008

Benzerara, K., Skouri-Panet, F., Li, J., Férard, C., Gugger, M., Laurent, T., et al. (2014). Intracellular Ca-carbonate biomineralization is widespread in Cyanobacteria. PNAS 111, 10933-10938. doi: 10.1073/pnas.1403510111

Borrok, D., Aumend, K., and Fein, J. B. (2007). Significance of ternary bacteriametal-natural organic matter complexes determined through experimentation and chemical equilibrium modeling. Chem. Geol. 238, 44-62. doi: 10.1016/j. chemgeo.2006.10.013

Bouzigues, C., Gacoin, T., and Alexandrou, A. (2011). Biological applications of rare-earth based nanoparticles. ACS Nano 5, 8488-8505. doi: 10.1021/ nn202378b 
Cason, E. D., Piater, L. A., and van Heerden, E. (2012). Reduction of U(VI) by the deep subsurface bacterium, Thermus scotoductus SA-01, and the involvement of the ABC transporter protein. Chemosphere 86, 572-577. doi: 10.1016/j. chemosphere.2011.10.006

Charrier, M., and Ajo-Franklin, C. M. (2017). "Engineering thermophilic microorganisms to selectively bind strategic metals in low temperature geothermal brines," in Proceedings of the 42nd Work on Geothermal Reservoir Engineering, (California, CA: Standford), 1-5.

Chen, A., Shi, Q., Feng, J., Ouyang, Y., Chen, Y., and Tan, S. (2010). Dissociation of outer membrane for Escherichia coli cell caused by cerium nitrate. J. Rare Earths 28, 312-315. doi: 10.1016/S1002-0721(09)60103-4

Chen, A., Shi, Q., Ouyang, Y., and Chen, Y. (2012). Effect of $\mathrm{Ce}^{3+}$ on membrane permeability of Escherichia coli cell. J. Rare Earths 30, 947-951. doi: 10.1016/ S1002-0721(12)60159-8

Das, D., Das, N., and Mathew, L. (2010). Kinetics, equilibrium and thermodynamic studies on biosorption of $\mathrm{Ag}(\mathrm{I})$ from aqueous solution by macrofungus Pleurotus platypus. J. Hazard. Mater. 184, 765-774. doi: 10.1016/j.jhazmat.2010. 08.105

Das, N., and Das, D. (2013). Recovery of rare earth metals through biosorption: an overview. J. Rare Earths 31, 933-943. doi: 10.1016/S1002-0721(12)60382-2

De Muynck, W., Verbeken, K., De Belie, N., and Verstraete, W. (2013). Influence of temperature on the effectiveness of a biogenic carbonate surface treatment for limestone conservation. Appl. Microbiol. Biotechnol. 97, 1335-1347. doi: 10.1007/s00253-012-3997-0

Diniz, V., and Volesky, B. (2005). Biosorption of La, Eu and Yb using Sargassum biomass. Water Res. 39, 239-247. doi: 10.1016/j.watres.2004.09.009

Dutta, T., Kim, K. H., Uchimiya, M., Kwon, E. E., Jeon, B. H., Deep, A., et al. (2016). Global demand for rare earth resources and strategies for green mining. Environ. Res. 150, 182-190. doi: 10.1016/J.ENVRES.2016.05.052

Emmanuel, E. S. C., Vignesh, V., Anandkumar, B., and Maruthamuthu, S. (2011). Bioaccumulation of cerium and neodymium by Bacillus cereus isolated from rare earth environments of chavara and manavalakurichi. India. Indian J. Microbiol. 51, 488-495. doi: 10.1007/s12088-011-0111-8

Erasmus, M., Cason, E. D., van Marwijk, J., Botes, E., Gericke, M., and van Heerden, E. (2014). Gold nanoparticle synthesis using the thermophilic bacterium Thermus scotoductus SA-01 and the purification and characterization of its unusual gold reducing protein. Gold Bull. 47, 245-253. doi: 10.1007/ s13404-014-0147-8

Gaspard, S., Vazquez, F., and Holliger, C. (1998). Localization and solubilization of the iron(III) reductase of Geobacter sulfurreducens. Appl. Environ. Microbiol. $64,3188-3194$.

Gunatilake, S. K. (2015). Methods of removing heavy metals from industrial wastewater. J. Multidiscip. Eng. Sci. Stud. 1, 12-18. doi: 10.13140/RG.2.1.3751. 1848

Haferburg, G., Merten, D., Büchel, G., and Kothe, E. (2007). Biosorption of metal and salt tolerant microbial isolates from a former uranium mining area. their impact on changes in rare earth element patterns in acid mine drainage. J. Basic Microbiol. 47, 474-484. doi: 10.1002/jobm.200700256

Hellebrandt, S. E., Hofmann, S., Jordan, N., Barkleit, A., and Schmidt, M. (2016). Incorporation of $\mathrm{Eu}(\mathrm{III})$ into calcite under recrystallization conditions. Nat. Publ. Gr. 6:33137. doi: 10.1038/srep33137

Hetzer, A., Daughney, C. J., and Morgan, H. W. (2006). Cadmium ion biosorption by the thermophilic bacteria Geobacillus stearothermophilus and G. thermocatenulatus. Appl. Environ. Microbiol. 72, 4020-4027. doi: 10.1128/ AEM.00295-06

Homer, R. B., and Mortimer, B. D. (1978). Europium II as a replacement for calcium II in concanavalin A A precipitation assay and magnetic circular dichroism study. FEBS Lett. 87, 69-72. doi: 10.1016/0014-5793(78) 80135-5

Hosomomi, Y., Baba, Y., Kubota, F., Kamiya, N., and Goto, M. (2013). Biosorption of rare earth elements by. J. Chem. Eng. Japan Escherichia coli, 450-454. doi: 10.1252/jcej.13we031

Jahn, B., Pol, A., Lumpe, H., Barends, T., Dietl, A., Hogendoorn, C., et al. (2018). Similar but not the same: first kinetic and structural analyses of a methanol dehydrogenase containing a europium ion in the active site. ChemBioChem 19, 1147-1153. doi: 10.1002/cbic.201800130

Jiang, K. Q., Zhao-Hui, G., Xi-Yuan, X., and Wei, X. Y. (2012). Effect of moderately thermophilic bacteria on metal extraction and electrochemical characteristics for zinc smelting slag in bioleaching system. Trans. Nonferrous Met. Soc. China 22, 3120-3125. doi: 10.1016/S1003-6326(11)61580-X

Kamennaya, N. A., Ajo-Franklin, C. M., Northen, T., and Jansson, C. (2012). Cyanobacteria as biocatalysts for carbonate mineralization. Minerals 2, 338-364. doi: 10.3390/min2040338

Kamnev, A. A., Antonyuk, L. P., Tugarova, A. V., Tarantilis, P. A., Polissiou, M. G., and Gardiner, P. H. E. (2002). Fourier transform infrared spectroscopic characterisation of heavy metal-induced metabolic changes in the plantassociated soil bacterium Azospirillum brasilense Sp7. J. Mol. Struct. 610, 127-131. doi: 10.1016/S0022-2860(02)00021-2

Khawassek, Y. M., Eliwa, A. A., Gawad, E. A., and Abdo, S. M. (2015). Recovery of rare earth elements from El-Sela effluent solutions. J. Radiat. Res. Appl. Sci. 8, 583-589. doi: 10.1016/j.jrras.2015.07.002

Kieft, T. L., Fredrickson, J. K., Onstott, T. C., Gorby, Y. A., Kostandarithes, H. M., Bailey, T. J., et al. (1999). Dissimilatory reduction of Fe(III) and other electron acceptors by a Thermus isolate. Appl. Environ. Microbiol. 65, 1214-1221.

Kumar, S., Prakash, R., and Singh, V. (2015). Synthesis, characterization, and applications of europium oxide: a review. Rev. Adv. Sci. Eng. 4, 247-257. doi: 10.1166/rase.2015.1102

Kuroda, A., Tanaka, S., Ikeda, T., Kato, J., Takiguchi, N., and Ohtake, H. (1999). Inorganic polyphosphate in the origin and survival of species. Proc. Natl. Acad. Sci. U.S.A. 96, 14264-14269. doi: 10.1073/pnas.96.25.14264

Lewis, A. J., Komninou, A., Yardley, B. W. D., and Palmer, M. R. (1998). Rare earth element speciation in geothermal fluids from Yellowstone National Park, Wyoming, USA. Geochim. Cosmochim. Acta 62, 657-663. doi: 10.1016/S00167037(97)00367-0

Lo, Y. C., Cheng, C. L., Han, Y. L., Chen, B. Y., and Chang, J. (2014). Recovery of high-value metals from geothermal sites by biosorption and bioaccumulation. Bioresour. Technol. 160, 182-190. doi: 10.1016/j.biortech.2014.02.008

Lyu, S., Guo, Z., Pan, J., Yang, Y., Yang, W., Chen, H., et al. (2014). Effect of rare earth elements on vitamin $\mathrm{C}$ fermentation by mixed cultures. Int. J. Agric. Biol. 16, 1135-1140.

MacHalová, L., Pipíška, M., Trajteaová, Z., and Horník, M. (2015). Comparison of $\mathrm{Cd} 2+$ biosorption and bioaccumulation by bacteria-A radiometric study. Nov. Biotechnol. Chim. 14, 158-175. doi: 10.1515/nbec-2015-0024

Madrid, Y., and Camara, C. (1997). Biological substrates for metal preconcentration and speciation. Trends Anal. Chem. 16, 36-44. doi: 10.1016/S0165-9936(96)00075-1

Mahmoud, G. M., El Hazek, N. T., Farag, A. M., and El Hussaini, O. M. (2008). Separation of rare earth elements from sulfate leach liquor by heterocyclic nitrogen compound. J. Rare Earths 26, 544-551. doi: 10.1016/S1002-0721(08) 60134-9

Mercier, F., Alliot, C., Bion, L., Thromat, N., and Toulhoat, P. (2006). XPS study of $\mathrm{Eu}$ (III) coordination compounds: core levels binding energies in solid mixedoxo-compounds EumXxOy. J. Electron Spectros. Relat. Phenomena 150, 21-26. doi: 10.1016/j.elspec.2005.08.003

Mishra, B., Boyanov, M., Bunker, B. A., Kelly, S. D., Kemner, K. M., and Fein, J. B. (2010). High- and low-affinity binding sites for Cd on the bacterial cell walls of Bacillus subtilis and Shewanella oneidensis. Geochim. Cosmochim. Acta 74, 4219-4233. doi: 10.1016/j.gca.2010.02.019

Naik, M. M., and Furtado, I. (2017). "Interaction of Haloarchaea with metals," in Marine Pollution and Microbial Remediation, eds M. M. Naik and S. K. Dubey (Singapore: Springer), 143-151. doi: 10.1007/978-981-10-1044-6_9

Nikel, P. I., Chavarría, M., Martínez-García, E., Taylor, A. C., and de Lorenzo, V. (2013). Accumulation of inorganic polyphosphate enables stress endurance and catalytic vigour in Pseudomonas putida KT2440. Microb. Cell Fact. 12:50. doi: 10.1186/1475-2859-12-50

Obst, M., Dittrich, M., and Kuehn, H. (2006). Calcium adsorption and changes of the surface microtopography of Cyanobacteria studied by AFM, CFM, and TEM with respect to biogenic calcite nucleation. Geochem. Geophys. Geosyst. 7, 1-15. doi: 10.1029/2005GC001172

Opperman, D. J., and van Heerden, E. (2007). Aerobic Cr(VI) reduction by Thermus scotoductus strain SA-01. J. Appl. Microbiol. 103, 1907-1913. doi: 10.1111/j.1365-2672.2007.03429.x

Oves, M., Khan, M. S., and Zaidi, A. (2013). Biosorption of heavy metals by Bacillus thuringiensis strain OSM29 originating from industrial effluent contaminated north Indian soil. Saudi J. Biol. Sci. 20, 121-129. doi: 10.1016/j.sjbs.2012. 11.006 
Özdemir, S., Kılınç, E., Poli, A., and Nicolaus, B. (2013). Biosorption of heavy metals $\left(\mathrm{Cd}^{2+}, \mathrm{Cu}^{2+}, \mathrm{Co}^{2+}\right.$, and $\left.\mathrm{Mn}^{2+}\right)$ by thermophilic bacteria, Geobacillus thermantarcticus and Anoxybacillus amylolyticus: equilibrium and kinetic studies. Bioremediat. J. 17, 86-96. doi: 10.1080/10889868.2012.751961

Peng, L., Yi, L., Zhexue, L., Juncheng, Z., Jiaxin, D., Daiwen, P., et al. (2004). Study on biological effect of $\mathrm{La}^{3+}$ on Escherichia coli by atomic force microscopy. J. Inorg. Biochem. 98, 68-72. doi: 10.1016/j.jinorgbio.2003.08.012

Pol, A., Barends, T. R. M., Dietl, A., Khadem, A. F., Eygensteyn, J., Jetten, M. S. M., et al. (2014). Rare earth metals are essential for methanotrophic life in volcanic mudpots. Environ. Microbiol. 16, 255-264. doi: 10.1111/1462-2920.12249

Qian, C., Wang, R., Cheng, L., and Wang, J. (2010). Theory of microbial carbonate precipitation and its application in restoration of cement-based materials defects. Chinese J. Chem. 28, 847-857. doi: 10.1002/cjoc.201090156

Rao, N. N., and Kornberg, A. (1996). Inorganic polyphosphate supports resistance and survival of stationary-phase Escherichia coli. J. Bacteriol. 178, 1394-1400. doi: 10.1128/jb.178.5.1394-1400.1996

Saleem, M., Brim, H., Hussain, S., Arshad, M., and Leigh, M. B. (2008). Perspectives on microbial cell surface display in bioremediation. Biotechnol. Adv. 26, 151-161. doi: 10.1016/j.biotechadv.2007.10.002

Sánchez-Román, M., Puente-Sánchez, F., Parro, V., and Amils, R. (2015). Nucleation of Fe-rich phosphates and carbonates on microbial cells and exopolymeric substances. Front. Microbiol. 6:1024. doi: 10.3389/fmicb.2015. 01024

Silva, A. I. S., Lima, N. B. D., Simas, A. M., and Gonçalves, S. M. C. (2017). Europium complexes: luminescence boost by a single efficient antenna ligand. Am. Chem. Soc. Omega 2, 6786-6794. doi: 10.1021/acsomega.7b00647

Su, Y., Zheng, X., Chen, Y., Li, M., and Liu, K. (2015). Alteration of intracellular protein expressions as a key mechanism of the deterioration of bacterial denitrification caused by copper oxide nanoparticles. Sci. Rep. 5:15824. doi: $10.1038 /$ srep 15824

Uhrovčík, J., Gyeváthová, M., and Lesný, J. (2013). Possibility of the spectrophotometric determination of europium by means of arsenazo III. Nova Biotechnol. Chim. 12, 93-99. doi: 10.2478/nbec-2013-0011

Vijayaraghavan, K., and Yun, Y. S. (2008). Bacterial biosorbents and biosorption. Biotechnol. Adv. 26, 266-291. doi: 10.1016/j.biotechadv.2008.02.002
Volesky, B. (2001). Detoxification of metal-bearing effluents : biosorption for the next century. Hydrometallurgy 59, 203-216. doi: 10.1016/S0304-386X(00) 00160-2

Volesky, B. (2007). Biosorption and me. Water Res. 41, 4017-4029. doi: 10.1016/j. watres.2007.05.062

Wood, S. A., and Shannon, W. M. (2003). Rare-earth elements in geothermal waters from oregon, nevada, and california. J. Solid State Chem. 171, 246-253. doi: 10.1016/S0022-4596(02)00160-3

Xie, F., Zhang, T. A., Dreisinger, D., and Doyle, F. (2014). A critical review on solvent extraction of rare earths from aqueous solutions. Miner. Eng. 56, 10-28. doi: 10.1016/j.mineng.2013.10.021

Yu, M., Li, F., Chen, Z., Hu, H., Zhan, C., Yang, H., et al. (2009). Laser scanning upconversion luminescence microscopy for imaging cells labeled with rare-earth nanophosphors. Anal. Chem. 81, 930-935. doi: 10.1021/ac802072d

Zhu, T., and Dittrich, M. (2016). Carbonate precipitation through microbial activities in natural environment, and their potential in biotechnology: a review. Front. Bioeng. Biotechnol. 4:4. doi: 10.3389/fbioe.2016. 00004

Zhuang, W. Q., Fitts, J. P., Ajo-Franklin, C. M., Maes, S., AlvarezCohen, L., and Hennebel, T. (2015). Recovery of critical metals using biometallurgy. Curr. Opin. Biotechnol. 33, 327-335. doi: 10.1016/j.copbio.2015. 03.019

Conflict of Interest Statement: The authors declare that the research was conducted in the absence of any commercial or financial relationships that could be construed as a potential conflict of interest.

Copyright (๑ 2019 Maleke, Valverde, Vermeulen, Cason, Gomez-Arias, Moloantoa, Coetsee-Hugo, Swart, van Heerden and Castillo. This is an open-access article distributed under the terms of the Creative Commons Attribution License (CC BY). The use, distribution or reproduction in other forums is permitted, provided the original author(s) and the copyright owner(s) are credited and that the original publication in this journal is cited, in accordance with accepted academic practice. No use, distribution or reproduction is permitted which does not comply with these terms. 